\title{
Globalization, Free Trade, And Outsourcing: A College Student's Perspective - Part III
}

\author{
K. Morris (Moshe) Speter, Mercy College, USA
}

\begin{abstract}
As globalization becomes a growing factor in the US business world, it is important to understand what college students know and think about the subject. In the beginning of 2008, a survey was undertaken among a convenient and disperse group of students. The survey was conducted in NY and Connecticut among undergraduate and graduate students. The survey results were presented at Thirty Fifth Northeast Business \& Economic Association conference in November 2008. Between the time that the first survey was taken and the second, there have been seismic changes in the US. Then the elected president was George W. Bush, a Republican, and today the president elect is Barak H. Obama, a Democrat. The Republicans, in general, and President Bush, in particular, were "internationalists" and strong advocates of free trade. The Democratic party philosophy was more domestically-oriented being anti-free trade, in general, and NAFTA, in particular. Additionally, the economic situation was perceptually better then than now. These changes were reflected in the attitudes of the college students that were surveyed. In 2009, the survey was repeated. After a devastating economic decline worldwide with millions of jobs lost in the US, the attitudes of college students in NY were again surveyed to measure any impact on their attitudes on globalization.
\end{abstract}

Keywords: Globalization, Free Trade, NAFTA, Free Trade

\section{INTRODUCTION}

lobalization is defined by Miriam Webster as "the act or process of globalizing: the development of an increasingly integrated global economy marked especially by free trade, free flow of capital, and the tapping of foreign labor markets". There is no question that globalization has had a very positive impact on developing countries. China has become the manufacturing center of the world and the US has benefited from an endless stream of low-cost imports. However, as the current economic crisis has shown, there are two sides to the story. Out-increasing interdependence has caused the crisis to spread everywhere. The economic downturn in the US and Europe is resulting in fewer orders from China and other countries. Millions of American jobs have disappeared and the domestic + foreign debt of the US has mushroomed. NAFTA has also become a symbol of US "losing" to others and much concern is expressed about the US's ability to compete and its "unfavorable" position when it comes to trade. As we close out the first year of the Obama administration, slowly recovering from the economic downturn, it is very important to gauge what the future leaders (i.e. college students) think about the subject of globalization. Though the subject has a political dimension, it is mostly related to business. As such, students who are studying in the business administration program, at the undergraduate level, were surveyed for this study.

\section{APPROACH}

The study is more directional in nature than being "statistically significant" in its findings. It was conducted among a "convenient sample" of students studying in NY and Connecticut colleges. The common points were geography (i.e. NY and CT), level (i.e., graduate and undergraduate), and timing (first quarter and fourth quarter of 2008). The third round, in the $4^{\text {th }}$ quarter of 2009, only surveyed students in NY and will be compared to previous students with the same demographics. Though not precisely a longitudinal study (i.e. tracking the same students over time) the study participants represent very similar demographics and their responses can be viewed 
with some confidence as representing a population of cohorts. Following are the results of the study:

\section{RESULTS}

1. Awareness of globalization was widespread. Whether NY $(98 \%)$ or undergraduate $(96 \%)$, in the first quarter $(97 \%)$ or the second (97\%), it is quite apparent that at least familiarity with the term is universal. In the last study, $100 \%$ of students knew what globalization was.

2. NAFTA was only slightly less known. By the fourth quarter of $2008,90 \%$ of undergraduates have heard of NAFTA. In the fourth quarter of $2009,88 \%$ heard of NAFTA

3. Positive opinions of NAFTA declined in 2008 , from $90 \%$ to $82 \%$, among undergraduate students in 2008 , to $71 \%$ in 2009.

4. Similarly, the preferences for having more agreements, like NAFTA, were stable. Among undergraduates, the numbers were virtually identical at $69 \%$ in the fourth quarter vs. $67 \%$ in 2008 and $75 \%$ in 2009.

5. Awareness of outsourcing was also virtually universal, ranging from $87 \%$ in the $4^{\text {th }}$ quarter vs. $86 \%$ in $1^{\text {st }}$ quarter 2008 and $92 \%$ in 2009.

6. Positive opinions of outsourcing declined in 2008. By the $4^{\text {th }}$ quarter, $51 \%$ of undergraduate students thought outsourcing was a good idea. In the $1^{\text {st }}$ quarter, the numbers were $54 \%$, respectively. Unexpectantly, the numbers rose to $70 \%$ in 2009 .

7. On the question as to whether outsourcing benefited the US among undergraduate students, $65 \%$ of undergraduates thought there was a benefit as shown by an increase from $51 \%$ in 2008 . In 2009, there was a further increase in positive attitudes to the level of $72 \%$.

8. Support for laws to outlaw outsourcing surprisingly declined in 2008 given the economic and political changes during the year. By the $4^{\text {th }}$ quarter, $41 \%$ of undergraduates (down from 54\%) would support such laws. In 2009, the number supporting such laws increased slightly to $45 \%$

9. Stopping outsourcing had a mixed reaction over the year. In the $4^{\text {th }}$ quarter, $39 \%$ of undergraduates would stop US companies from outsourcing, down from 53\%, respectively, in the $1^{\text {st }}$ quarter of 2008. In 2009, the number was further reduced to $27 \%$.

10. Finally, $80 \%$ of undergraduate students would "embrace" globalization by the end of 2008 , which was an increase among undergraduates, from $75 \%$ in the $1^{\text {st }}$ quarter. By $2009100 \%$ of undergraduate students surveyed thought that we should embrace globalization.

\section{IMPLICATIONS}

What does the data reflect and what does it mean? The term globalization is universally known, and acceptance of it has increased in 2009. Outsourcing and NAFTA are also very well known, but are seen as being less beneficial to the US as the time progressed. However, the number of students with opinions as to whether outsourcing should be outlawed was relatively stable at less than half of those surveyed supporting outlawing outsourcing. For the Obama administration, this may be an indication that being anti-free trade may be a popular position to take, but to support such a stance may be problematic in the long term. Only a minority of students would support "outlawing" or stopping outsourcing. From a political perspective, it would seem to be more effective to help American companies produce domestically in a competitive manner rather than punish outsourcing efforts.

There is no question as to an anxiety in the US due to the economic situation. Anti-foreign feelings may run high, but in the final analysis, it seems that college students overwhelmingly "embrace" the concept of globalization.

\section{CONCLUSIONS}

As noted previously, this study needs to be viewed as directional. There are many limitations to the research, ranging from sample size issues to definitional issues. However, it would seem that there is a growing concern about the positive value of NAFTA and outsourcing. Consequently, the president has to focus on improving American competitiveness in the global marketplace with a positive message. Being anti-internationalism may work in the short term, but it appears that the idea of globalization is well known and embraced by a vast majority of college students. 


\section{AUTHOR INFORMATION}

Dr. K. Morris (Moshe) Speter has significant (25 years) corporate and academic (13 years) experience. He currently teaches Marketing and International Business at Mercy College and has been doing research about economic development in Africa and China and the impact of Globalization. He has published more than 60 papers and presented many of them at various academic conferences. His next area of interest will be Eastern Europe and the transitional experience from communism to capitalism.

\section{REFERENCES}

1. Merriam Webster ONLINE.2005 by Merriam-Webster, Incorporated http://www.Merriam-Webster.com

2. Speter, Morris, Globalization, Free Trade and Outsourcing - A College Student's Perspective, Northeast Business \& Economic Association Thirty Fifth Annual Conference, Melville, NY, November 6-8 2008.

3. Speter, Morris. Globalization, Free Trade and Outsourcing - A College Student's Perspective Part II, Knowledge Globalization Conference, Knowledge Globalization Institute, Boston MA April 17-19, 2009. wikipedia.org/wiki/Globalization. 
NOTES 